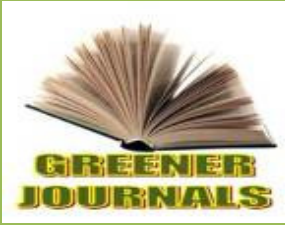

\title{
Inoculation of Bradyrhizobium japonicum (Kirchner, 1896) Jordan (1982) (Bradyrhizobiaceae) on Inga edulis Mart. (Leguminosae, Mimosoideae)
}

\section{Freitas $\mathrm{J}^{\star 1}$, Mônico $A Z^{1}$, Lírio $\mathrm{EJ}^{2}$, Sarnaglia-Jnr $\mathrm{VB}^{2}$, Bonadeu $\mathrm{F}^{2}$, Silva JBNF $^{3}$ \& Hebling SA ${ }^{4}$}

\begin{abstract}
${ }^{1}$ Centro Universitário Norte do Espírito Santo - CEUNES/UFES. Rodovia BR 101 Norte, km. 60, Bairro Litorâneo, São Mateus - ES, Brazil, 29932-540.

2Escola Nacional de Botânica Tropical, Instituto de Pesquisas Jardim Botânico do Rio de Janeiro. Rua Pacheco Leão, 915, sala 107, Jardim Botânico, Rio de Janeiro - RJ, Brazil, 22460-038.

${ }^{3}$ Centro de Ciências e Saúde (CCS), Universidade Federal do Rio de Janeiro. Av. Carlos Chagas Filho 373, Bloco J sala 25, Ilha do Fundão, Rio de Janeiro, RJ, Brazil, 22541-900.

${ }^{4}$ Faculdade Católica Salesiana do Espírito Santo. Av. Vitória, a950, Forte São João, Vitória - ES, Brazil, 29017-950.
\end{abstract}

ARTICLE INFO

Article No.: 063014287

DOI: 10.15580/GJAS.2016.3.063014287

Submitted: 30/06/2014

Accepted: 28/07/2014

Published: 28/03/2016

${ }^{*}$ Corresponding Author

Freitas $J$

E-mail: joelciofr@gmail.com \& naldinhozm@gmail.com

Keywords:

Fabaceae, rhizobia, legume, agricultural crop
Legumes that have the ability to fix atmospheric nitrogen through symbiosis with bacteria known as rhizobia, have great importance from an economic and ecological perspective, because in agricultural crops and reforestation, may waive the use of nitrogenous fertilizers and provide more resistant seedlings, minimizing impacts in nature and low cost. Bradyrhizobium japonicum (Kirchner, 1896) Jordan (1982) (Bradyrhizobiaceae) is a rhizobium which has association with several species of the subfamily Papilionoideae. This study aimed to analyze the initial growth of Inga edulis Mart (Leguminosae, Mimosoideae) inoculated with $B$. japonicum to test interaction in the subfamily Mimosoideae. We used the parameters: height, stem diameter and number of expanded leaves; data analysis consisted of the Shapiro-Wilk normality test. The inoculated seedlings showed a significant difference for height and number of leaves, but no significant difference for stem diameter. From the results, it is inferred that $l$. edulis presents positive interaction with $B$. japonicum, i.e., the interaction of rhizobia extends to Mimosoideae, which allows to infer that the interaction of rhizobia can be shown as homologous synapomorphy of the clade Mimosoideae-Papilonoideae, which is supported by molecular phylogenies. The results are compared with other studies and the implications in the evolution of the clades of the Leguminosae are discussed in phylogenetic studies. To corroborate the hypothesis, further studies of species of different subfamilies of these clades should be tested in order to verify that indeed this interaction is a homologous synapomorphy of the clade or an apomorphy for Mimosoideae, Leguminosae and interaction with B. japonicum has arisen more than once in the evolution scale of the family. 
RESUMO (ABSTRACT IN PORTUGUESE)

Leguminosas tem a capacidade de fixar nitrogênio atmosférico através da simbiose com bactérias, conhecidas como rizóbios, tem grande importância sob ponto de vista econômico e ecológico, pois em cultivos agrícolas e reflorestamentos, podem dispensar o uso de fertilizantes nitrogenados e propiciar mudas mais resistentes, o que minimiza os impactos desses insumos na natureza e diminui os custos. Bradyrhizobium japonicum (Kirchner, 1896) Jordan (1982) (Bradyrhizobiaceae) é um rizóbio com associação com diversas leguminosas de Papilionoideae. 0 presente trabalho teve por objetivo analisar o crescimento inicial de indivíduos de Inga edulis (Leguminosae, Mimosoideae) submetidas à inoculação do rizóbio a fim de testar a interação deste em Mimosoideae, filogeticamente, grupo irmão de Papilionoideae. Foram utilizados os parâmetros altura, diâmetro do caule e número de folhas; a análise dos dados consistiu no teste de normalidade de Shapiro-Wilk. A partir dos resultados, é inferido que $l$. edulis apresenta interação positiva com B. japonicum. Os resultados são confrontados com outros trabalhos e as implicações na evolução dos clados de Leguminosae são discutidos com estudos filogenéticos.

Palavras-chave: Fabaceae, rizóbios, leguminosa, cultivo agrícola.

\section{INTRODUCTION}

Nitrogen-fixing bacteria, known as rhizobia (e.g. Bradyrhizobium e Rhizobium) are species that live in a symbiotic relationship with plants, mainly legumes. The legume-rhizobium symbiosis is the source of fixed nitrogen that supply this element to the plant and in return receive carbon from the host plant (Taiz and Zeiger, 2004; Souchie et al., 2005). The rhizobia species can improve the development of seedlings in nurseries and tillage (Barnett and Baker, 1999; Moreira, 1994), increases disease tolerance (Green et al., 1999), maximizing the ability to establish these seedlings in the field, which assists in reforestation (Souchie et al., 2005).

The leguminosae are flowering plants with significant importance on component of forests in terms of richness and density, especially in biomes such as the Amazon, Cerrado and Atlantic Rainforest (BFG, 2015). The family has interaction with various rhizobial species (Jesus et al., 2005; Perret et al., 2000), most often the subfamilies Papilionoideae and Mimosoideae, uncommon in Caesalpinoideae (Souza et al., 1994; Moreira, 1994; Barberi et al., 1998). Molecular data support that the family is monophyletic, as well as the Mimosoideae and Papilionoideae subfamilies, but Caesalpinioideae is paraphyletic (Wojciechowski, 2003; Wojciechowski et al., 2004). In the present work, we use Caesalpinioideae term to refer this basal grade. For legumes there are records of interaction with several bacteria families: Xanthobacteraceae, Hyphomicrobiaceae, Phyllobacteriaceae, Methylobacteriaceae, Brucellaceae, Burkolderiaceae, Rhizobiaceae and Bradyrhizobiaceae (Moreira, 2008; Gyaneshwar et al., 2011).

Bradyrhizobium japonicum (Kirchner, 1896) Jordan (1982) (Bradyrhizobiaceae) is a important rhizobium species which has symbiotic interaction with many Papilionoideae (Leguminosae) species (Lírio et al., 2012) and is widely used to improve the production of Glycine max (L.) Merr, popularly known as "soy" in agricultural systems (Ruiz-Díez et al., 2012). However, no tests have been carried out with species of other legume subfamilies.

A typical legume species of South America is Inga edulis Mart. (subfamily Mimosoideae), found along the Atlantic Rainforest, Caatinga and Amazon Rainforest (Pennington, 1997; BFG, 2015) very much utilized by communities as food source, timber and medicine, especially by Andean countries (Pennington, 1997). Furthermore, is used in the Amazon in agroforestry systems to improve soil fertility and to shade in perennial crops as coffee and cacao (Lojka et al., 2010).

Once $B$. japonicum is capable of interacting with Papilionoideae species, and nodulation is considered by some authors an important taxonomic character (Faria and Sprent, 1994) the aim of this article was to evaluate whether the interaction of $B$. japonicum extends to Mimosoideae, the Papilionoideae sister group. In this context, we evaluated the initial development of $I$. edulis inoculated with $B$. japonicum.

\section{MATERIAL AND METHODS}

\section{Study Area}

The work was performed in the experimental field of the São Francisco de Assis School, in the municipality of Santa Teresa, Espírito Santo state, Brazil (19 ${ }^{\circ} 56^{\prime} 10^{\prime \prime}$ S; $40^{\circ} 36^{\prime} 06^{\prime \prime} \mathrm{W}$ ). The elevation of the region is $650 \mathrm{~m}$ (Mendes and Padovan, 2000). The $l$. edulis seeds were collected in a private property localized in the municipality of Afonso Cláudio, Espírito Santo state, Brazil (2004' 26" S; $\left.41^{\circ} 07^{\prime} 32 \mathrm{~W}\right)$.

\section{Experimental Design}

A total of 200 seeds was used, $50 \%$ were inoculated and the rest used as control that were placed in tillage on soil, and after sowing, kept in full sun. We obtained $B$. japonicum (strain 5080) on peat substrate (Nitrosuper F45). To inoculation we diluted the bacteria in distilled 
water as carried out in Lírio et al. (2012). The dilution consisted of $1 \mathrm{~mL}$ of solution bacteria and $3 \mathrm{~mL}$ of distilled water for $5 \mathrm{~g}$ of seeds and they were protected from sunlight at the time of sowing. Height, stem diameter and number of expanded leaves parameters were measured two months after seeding.

\section{Statistical Analysis}

Statistical analysis was performed using the PAST software (Hammer et al., 2001). We used the ShapiroWilk (Shapiro and Wilk, 1965) test for normality. The $t$ test was used for the comparison of data obtained for the inoculated and control samples, with a significance level of $0.05 \%$.

\section{RESULTS AND DISCUSSION}

The data are normally distributed in the comparison of all parameters, which justified the use of the t-Student test (tab. 1). The treatment of $I$. edulis presents significant difference in the parameters height and number of sheets and did not show significant difference to stem diameter (fig. 1). The results suggest that the interaction of $B$. japonicum occur in $I$. edulis, included in the subfamily Mimosoideae.

Table 1: Results of the normality test Shapiro-Wilk, N=20 ("hgt" = height, "Ivn" = leaves number, "stmd" = stem diameter, " $\mathrm{i}=$ inoculated and "c" = control)

\begin{tabular}{lllllll}
\hline & hgt_i & Ivn_i & stmd_i & hgt_c & Ivn_c & stmd_c \\
\hline Shapiro-Wilk W & 0.9788 & 0.9073 & 0.9694 & 0.9544 & 0.9309 & 0.9671 \\
p (normal) & 0.9175 & 0.05667 & 0.7425 & 0.4385 & 0.1604 & 0.693 \\
\hline
\end{tabular}

Figure 1: Barchat showing the mean and standard
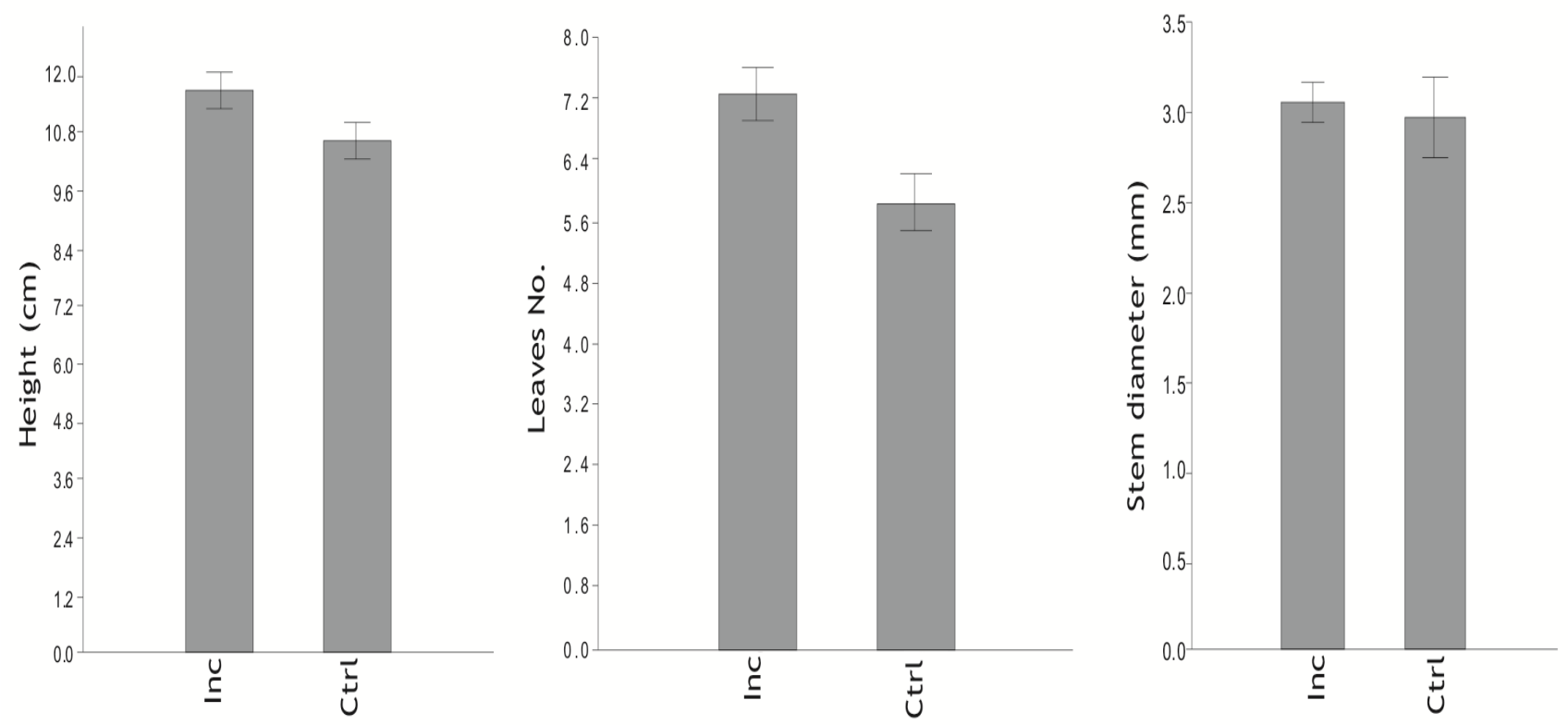

error for height $(n=20 ; t=2.338 ; p=0.03046)$, leaves number $(n=20 ; t=2.833 ; p=0.01063)$ and stem diameter $(n=20 ; t=0.3451 ; p=0.7338)$, respectively. "Inc" = inoculated sample and "Ctrl" = control sample 
Leblanc et al. (2005) isolated four Bradyrhizobium strains of $I$. edulis, and through BLAST analysis came to the conclusion that these strains are closely related (with molecular data) to B. japonicum ( $96 \%$ similar), however they consider that there was insufficient information of $B$. japonicum affiliation for strong conclusions.

The phylogenetic relationship of Leguminosae subfamilies is supported by molecular studies, which Papilionoideae and Mimosoideae are sister groups (Wojciechowski, 2003; Wojciechowski et al., 2004). Analyzing the interaction of legumes with rhizobia, other studies corroborate this pattern, where it is proposed that there are a gradual trend of interaction: Papilionoideae with the highest number of species with interaction, followed by Mimosoideae and Caesalpinioideae, with the lowest number of species (Souza et al., 1994; Barbieri et al., 1998). Possibly the smallest interaction with Caesalpinioideae is due the fact that the group is more basal in the evolution scale of Leguminosae, and that the interaction of the family with rhizobia arose in the period that Caesalpinioideae has been established (Faria et al., 1984; Barbieri et al., 1998). It is possible that the ability to interact with rhizobia has arisen more than once in the scale of evolution of the family, as has been proposed (Sprent, 2001; Doyle and Luckow, 2003), however, the specificity by rhizobia with different clades or species (Perret et al., 2000; Miller et al., 2007; Wang et al., 2012), permits the inference that the interaction of several species of rhizobia can be seen to be homologous synapomorphies of Leguminosae clades as inferred for $B$. japonicum in Mimosoideae + Papiloinoideae. In Papilionoideae 11 species nodulate with $B$. japonicum, which belong to the tribes Phaseoleae, Genisteae and Loteae (Lírio et al., 2012). Furthermore, Perret et al. (2000) cite three tribes as non-host of $B$. japonicum: Vicieae, Cicereae and Trifolieae. These absences of interaction can be explained as a single reversal, since phylogenetic analysis indicated that these tribes form a monophyletic clade called by Steele and Wojciechowski (2003) as "vicioid clade". Based on parsimony, is possible to infer that the nodulation of $B$. japonicum with Leguminosae may have arisen in the common ancestor of Papilionoideae and Mimosoideae.

\section{CONCLUSIONS}

According to the results, $B$. japonicum has positive interactions with $l$. edulis. This interaction may be a synapomorphy of the clade Papilionoideae + Mimosoideae. To corroborate our hypothesis that $B$. japonicum interacts with Papilionoideae and Momosoideae, but not with Caesalpinioideae, other studies with species of different subfamilies clades should be evaluated. Particularly between Mimosoideae and Caesalpinioideae to verify if this interaction is a homologous synapomorphy of Papilionoideae +
Mimosoideae clade, or should be an apomorphy for Mimosoideae, and the interaction of $B$. japonicum group has arisen more than once in the scale of Leguminosae evolution.

Also we propose studies with native rhizobia species which can be isolated from other legumes, not only by the potential to elucidate evolutionary interactions between rhizobia and Leguminosae, but also by the economic and ecological importance that can make in agricultural crops and reforestation. Another aim to be evaluated is the effects caused by introduction of exotic rhizobia to local biodiversity. The studies should be performed by isolation of rhizobia in native legume species from adjacent crops areas, mainly of soy, once $B$. japonicum strains that have been inoculated in large scale (Ruiz-Díez et al. 2012). Furthermore, studies on competition with native rhizobia or negative interactions with local biodiversity are needed.

\section{ACKNOWLEDGMENTS}

The authors thank the Escola Superior São Francisco de Assis, the Atlantic Forest Resaerch Institute (Museu de Biologia Prof. Mello Leitão), CAPES, and the biologists Adriano Totola, Braz Pereira Lopes, Eleisson Loss, Mariana Soares Colombi and Wesley Croce for their contributions to this work.

\section{COMPETING INTEREST}

The authors declare that they have no competing interest.

\section{AUTHOR'S CONTRIBUTION}

JF and AMZ conducted the experiments. VBSJ performed the statistical tests. JF, AMZ, EJL, BN and FB organized and discussed the results. SAH performed the study design and supervised the work. All authors read and approved the final manuscript.

\section{REFERENCES}

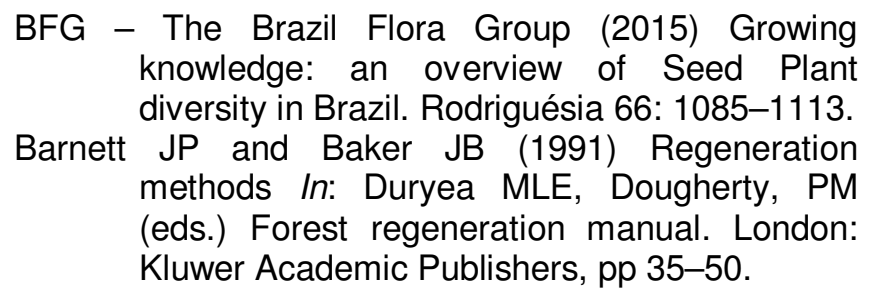


Barberi A, Carneiro MAC, Moreira FMS and Siqueira JO (1998) Nodulação em Leguminosas florestais em viveiros no sul de Minas Gerais. Cerne 4 (1):145-153.

Doyle JJ and Luckow MA (2003) The rest of the iceberg. Legume diversity and evolution in a phylogenetic context. Plant Physiology 131:900-910.

Faria SM, Franco AA, Jesus RM, Menandro M de S, Baitello JB, Mucci ESF, Dobereiner $\mathrm{J}$ and Sprent JI (1984). New nodulating legume trees from southeast Brazil. New Phytologist 98:317-328.

Faria SM and Sprent JI (1994) Legume nodule development: an evolutionary hypothesis. In: Sprent, $\mathrm{JI}$ and Mckey, D (Eds.). Advances in Legume Systematics, 5: The nitrogen factor, Royal Botanical Garden, Kew, pp 33-39.

Green H, Larsen J, Olsson OA, Jensen DF and Jacobsen I (1999) Suppression of the biocontrol agent Trichoderma harzianum by mycelium of the arbuscular mycorrhizal fungus Glomus intraradices in toot-free soil. Applied Environmental Microbiology 65 (4):14281434.

Gyaneshwar P et al. (2011) Legume-Nodulating Betaproteobacteria: Diversity, Host Range, and Future Prospects. The American Phytopathological Society 24 (11):1276-1288.

Hammer $\varnothing$, Harper DAT and Ryan PD (2001) Past: paleontological statistics software package for education and data analysis. Palaeontologia Electronica 4:1-9.

Jesus EC, Schiavo JÁ and Faria SM (2005) Dependência de micorrizas para a nodulação de leguminosas arbóreas tropicais. Revista Árvore 29 (4):545-552.

Jordan DC (1982) Transfer of Rhizobium japonicum Buchanan 1980 to Bradyrhizobium gen. nov., a genus of slow-growing, root nodule bacteria from leguminous plants. International Journal of Systematic Bacteriology 32 (1):136-139.

Lírio EJ, Arnholz E, Hencker C, Roldi MMC, Soares RB, Sarnaglia-Jr VB, Bonadeu $F$ and Hebling $S$ (2012) Efeito da inoculação de Bradyrhizobium japonicum (Bradyrhizobiaceae) sobre o desenvolvimento de Senna multijuga e Phaseolus vulgaris (Fabaceae). Natureza On line 10 (4):195-199.

Lojka B, Dumas L, Preininger D, Polesny $Z$ and Banout $J$ (2010) The use and integration of Inga edulis in agroforestry systems in the Amazon - review article. Agricultura Tropica et Subtropica 43 (4):352-359.

Mendes SL and Padovan MP (2000) A Estação Biológica de Santa Lúcia. Boletim do Museu de Biologia Mello Leitão (N. série) 11/12:7-34.

Miller SH, Elliot RM, Sullivan JT and Ronson CW (2007) Host-specific regulation of symbiotic nitrogen fixation in Rhizobium leguminosarum biovar trifolii. Microbiology 153 (9):31843195.

Moreira FMS (1994) Fixação biológica do nitrogênio em espécies arbóreas In: Araujo RS, Hungria M (Eds) Microrganismos de importância agrícola. Brasília: EMBRAPA-SPI pp 121-150.

Moreira FMS (2008) Bactérias fixadoras de nitrogênio que nodulam Leguminosae. In: Biodiversidade do solo em ecossistemas brasileiros. Moreira, F.M.S.; Siqueira, J.O. \& Brussaard, L. (Eds.), Lavras, UFLA, pp 621-680.

Pennington TD (1997) The Genus Inga. Botany. Royal Botanical Garden, Kew.

Perret X, Staehelin C and Broughton WJ (2000) Molecular basis of symbiotic promiscuity. Microbiology and Molecular Biology Reviews 64:180-201.

Ruiz-Díez B, Fajardo S, Felipe MR de and FernándezPascual M (2012) Characterization of rhizobia from legumes of agronomic interest grown in semi-arid areas of Central Spain relates genetic differences to soil properties. Journal of Basic Microbiology 52:66-78.

Shapiro SS and Wilk MB (1965) $\mathrm{Na}$ analysis of variance test fornormality (complete samples). Biometrika 52:591-611.

Souchie EL, Campello EFC, Saggin-Júnior OJ and Silva EMR (2005) Mudas de espécies arbóreas inoculadas com bactérias solubilizadoras de fosfato e fungos micorrízicos arbusculares. Floresta 35:329334.

Souza LAG, Silva MF and Moreira FW (1994) Capacidade de nodulação de cem leguminosas da Amazônia. Acta Amazônica $24(2): 9-18$.

Sprent, J.I (2001) Nodulation in legumes. Royal Botanic Gardens, Kew, 156 p.

Steele KP and Wojciechowski MF (2003) Phylogenetic analyses of tribes Trifolieae and Vicieae based on sequences of the plastid gene matK (Papilionoideae: Leguminosae) In: Klitgaard BB and Bruneau A (eds.) Advances in Legume Systematics, part 10, higher level systematics. Royal Botanic Gardens, Kew, pp 355-370.

Taiz L and Zeiger E (2004) Fisiologia Vegetal. Artmed Editora S.A., Porto Alegre.

Wang D, Yang S, Tang F and Zhu H (2012) Symbiosis specificity in the legume: rhizobial mutualism. Cell Microbiology 14 (3): 334-342.

Wojciechowski MF (2003) Reconstructing the phylogeny of legumes (Fabaceae): an early 21st century perspective In: Klitgaard BB and Bruneau A (eds.) Advances in Legume Systematics, part 10, higher level systematics. Royal Botanic Gardens, Kew, pp 5-35. 
Wojciechowski MF, Lavin Mand Sanderson MJ (2004) A phylogeny of legumes (Leguminosae) based on analysis of the plastid matK gene resolves many well-supported subclades within the family. American Journal of Botany 91: 18461862.

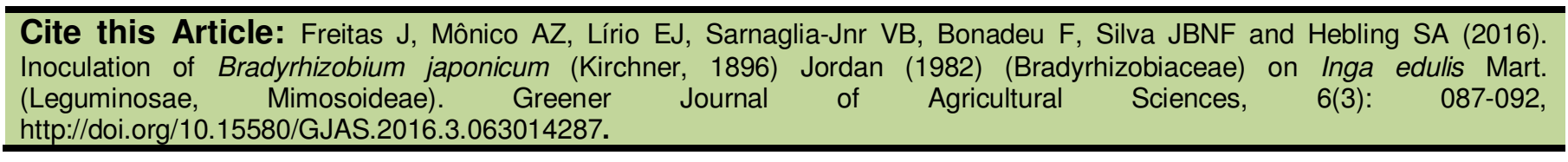

